\title{
COMPARISON AMONG PRE-GELATINIZED STARCHES OF DIFFERENT BOTANICAL ORIGINS USED IN NOBLE CRAYFISH ASTACUS ASTACUS DIETS
}

\author{
E. D'AGARO (1), M. MECATTI (2)
}

(1) Dipartimento di Scienze Animali, Università di Udine, Via s. Mauro 233010 Pagnacco (UD), Italy.

E-Mail: dagaro.edspa@univ.it

(2) Dipartimento di Scienze Zootecniche, University of Florence, Italy.

Reçu le 6 juin 2005

Received June 6, 2005

Accepté le 12 décembre 2005

Accepted December 12, 2005

\begin{abstract}
The objective of the present experiment was to compare the biological value and the binding functionality of four pre-gelatinized starches (wheat, diet 1; waxy maize, diet 2; maize, diet 3 and potato, diet 4) used in crayfish diets. 360 juvenile of $A$. astacus (initial b.w.: $0.70 \pm 0.15 \mathrm{~g}$ ) were cultured in 12 tanks for $43 \mathrm{~d}$. Growth performance were significantly higher in crayfish fed diets containing wheat and waxy maize compared to those containing maize and potato pre-gelatinized starches. Disintegration in water and shear force tests of diets confirmed the superior binding capability of pre-gelatinized starches obtained from wheat and waxy maize. These results suggest that the pregelatinized wheat and waxy maize starches are the best choice for the production of diets for the noble crayfish.
\end{abstract}

Key-words: Astacus astacus, pre gelatinized starch, nutrition.

\section{COMPARAISON D'AMIDONS PRÉ-GÉLATINISÉS DE DIFFÉRENTES ORIGINES BOTANIQUES UTILISÉS DANS L'ALIMENTATION DE L'ÉCREVISSE NOBLE (ASTACUS ASTACUS)}

\section{RÉSUMÉ}

L'objectif de l'expérimentation était de comparer la valeur biologique et la force de liaison de quatre amidons pré-gélatinisés (blé, régime 1 ; maïs " cireux ", régime 2 ; maiis, régime 3 ; pommes de terre, régime 4). 360 A astacus juvéniles (poids moyen initial : $0,70 \pm 0,15 \mathrm{~g}$ ) ont été élevés dans 12 bacs pendant 43 jours. Les performances de croissance ont été significativement plus élevées chez les écrevisses alimentées avec un régime contenant des amidons de blé ou de maïs " cireux ", comparées à celles alimentées avec un régime contenant des amidons de maïs ou de pommes de terre. La désintégration dans l'eau et les simples tests de traction des différents aliments expérimentaux ont confirmé la capacité supérieure de liaison des amidons pré-gélatinisés de blé ou de maïs. Ces résultats suggèrent que les amidons pré-gélatinisés de blé et de maïs cireux sont les meilleurs pour l'alimentation de l'écrevisse noble en élevage.

Mots-clés : Astacus astacus, amidon pré-gelatinisé, nutrition. 


\section{INTRODUCTION}

Preparation of practical diets in crayfish farming is particularly important because of the loss of nutrients into the water and the intermittent rather than immediate feed intake of crustaceans. Levels in excess of the essential nutrients are generally used in practical diets in order to provide adequate margins of safety. The amounts of leaching of dry matter and main nutrients and the measure of physical and chemical stability are the traditional methods for the evaluation of diets for crayfish (HASTINGS, 1964; HASTINGS et al., 1971; CUZON et al., 1994; BOONYARATPALIN and NEW, 1995).

The objectives of this study were to evaluate the effects of four pre-gelatinized starches utilized as ingredient of diets on growth performance of noble crayfish and on water stability and total hardness of the diets.

\section{MATERIAL AND METHODS}

The experimental trials were carried out at the Department of Animal Science, University of Udine (Italy). Four different starch sources (wheat, diet 1; maize waxy, diet 2; maize, diet 3 and potato, diet 4) were tested using experimental diets (crude protein, $28.4 \pm 0.5 \% \mathrm{DM}$ and ether extract, $6.2 \pm 0.4 \% \mathrm{DM}$ ). Pre-gelatinized starches were gently donated by Roquette Italia (Cassano Spinola, AL). The pre-gelatinized starch was the main ingredient of the experimental diets (32\%). Diets were pelleted into spaghetti like strands using a meat mincer in the laboratory of the department. The moist spaghetti were dried in an oven at $60^{\circ} \mathrm{C}$ for $24 \mathrm{~h}$ and then broken into small pieces.

Summerling Astacus astacus were bought in Germany (Ausburg) at the First Bavarian Crayfish Hatchery. 360 A. astacus juveniles (initial b.w.: $0.70 \pm 0.15 \mathrm{~g}$ ) were randomly allotted in 9 tanks $\left(1 \mathrm{~m}^{2} \times 0.6 \mathrm{~m}\right)$ and cultured for 43 days. Temperature, dissolved oxygen and other water parameters were measured weekly $\left(\mathrm{T}: 14.8^{\circ} \mathrm{C} ; \mathrm{O}_{2}: 7.0 \mathrm{mg} / \mathrm{l} ; \mathrm{pH}: 7.3 ; \mathrm{N}-\right.$ $\mathrm{NH}_{4}: 0.07 \mathrm{mg} / \mathrm{l} ; \mathrm{N}-\mathrm{NO}_{2}: 0.05 \mathrm{mg} / \mathrm{l} ; \mathrm{N}-\mathrm{NO}_{3}: 28.3 \mathrm{mg} / \mathrm{l}$ ) (APHA, 1980). Each tank contained a porous stone aerator and received a continuous flow of water. Mortality rate was recorded at each weighing and crayfish were weighed once a fortnight. Crayfish were fed by automatic feeders 6 times daily. The daily feed allotment was equally divided into morning, afternoon and night. Uneaten pellets were collected daily before 9 a.m.. Feed allotment (2\% b.w.) was adjusted weekly according to the expected weight. A photoperiod of $12 \mathrm{~h}$ light daily was maintained during the experiments. During the experiment, samples of the diets were collected for proximate analysis (A.O.A.C., 1990) and to determine the gross energy content by adiabatic bomb calorimeter. The shear strength of the diets were measured on 100 cylindrical pellets for each diet using an INSTRON 1011 tester (speed: $50 \mathrm{~mm} / \mathrm{min}$ ) equipped with a WARNER BRATZLER shear.

Leaching of dry matter and main nutrients were measured by immersing randomly in $12 \mathrm{I}$ aquaria $5 \mathrm{~g}$ (in triplicate) samples contained in nylon bags (porosity: $40 \mu \mathrm{m}$ ) for 1, 2, 4 and $8 \mathrm{~h}$. Temperature was kept constant at $15.1 \pm 0.43^{\circ} \mathrm{C}$. After the immersion, all samples were weighed, dried at $60^{\circ} \mathrm{C}$ and analysed for proximate analysis (AOAC 1990). Nitrogenfree extract (NFE) was determined by difference. Dry matter retention was calculated according to the formula proposed by JONES et al. (1996a).

Experimental data recorded during the growth and shear strength trials were subjected to one-way analysis of variance, GLM procedure, with the comparison between means made with the Duncan's multiple range test (SAS 1989).

\section{RESULTS}

The composition and proximate analysis of the experimental diets are reported in Table I and Table II, respectively. Diets were isoproteic and isoenergetic. 


\section{Table I}

Composition of the experimental diets.

Tableau I

Composition des régimes d'expérimentation.

\begin{tabular}{lc}
\hline \multicolumn{1}{c}{ Ingredients } & $\begin{array}{c}\text { Diet } \\
(\mathbf{g} / \mathbf{k g})\end{array}$ \\
\hline Fish meal & 200 \\
Soybean meal & 200 \\
Wheat middlings & 200 \\
Pre-gelatinized starch & 320 \\
Fish oil & 50 \\
Na alginate & 20 \\
Vit-min mix & 20 \\
\hline
\end{tabular}

Table II

Proximate analysis of the experimental diets.

Tableau II

Analyse proximate des régimes expérimentaux.

\begin{tabular}{llrrrr}
\hline \multicolumn{1}{c}{ Variables } & D1-Wheat & $\begin{array}{c}\text { D2-Waxy } \\
\text { Maize }\end{array}$ & D3-Maize & $\begin{array}{c}\text { D4- } \\
\text { Potato }\end{array}$ & $\begin{array}{c}\text { Err. Var. } \\
\text { (6 d.f.) }\end{array}$ \\
\hline Dry matter & \% & 93.8 & 92.3 & 94.6 & 94.5 \\
Crude protein & \% d.m. & 28.7 & 28.5 & 28.7 & 27.7 \\
Ether extract & \% d.m. & 5.8 & 6.4 & 6.0 & 6.7 \\
Crude fibre & \% d.m. & 2.3 & 3.0 & 2.7 & 2.9 \\
Ash & \% d.m. & 6.2 & 5.4 & 5.3 & 5.2 \\
N-free extract & \% d.m. & 57.0 & 56.7 & 57.3 & 57.5 \\
Gross energy & MJ/kg d.m. & 18.3 & 18.6 & 19.0 & 18.9 \\
\hline
\end{tabular}

Mean weight gain (Table III) for all dietary treatments ranged from 300 to $530 \mathrm{mg}$ after 43 days. Highest weight gain was obtained using diets 1 and 2 containing wheat and waxy maize, respectively, and the worst with diet 4 containing potato. Survival rate (40 crayfish per tank) ranging from 84 to $97 \%$ was lowest in crayfish fed diet 3 . Shear strength values (Table III) were significantly higher in diet 1 and 2.

Diet dry matter losses into the water are shown in Figure 1.

After $8 \mathrm{~h}$ of water exposure, lower dry matter losses were noted in diets containing wheat (diet 1) and waxy maize (diet 2) (average $1.36 \%$ and $1.23 \%$, respectively).

Variations in the nutrient concentrations after immersion into the water for 1, 2, 4 and 8 hours are shown in Figures 2 and 3.

After immersion in water, dietary protein and lipid concentrations increased and carbohydrate and mineral contents decreased.

Disintegration in water and shear force tests confirmed the superior binding capability of pre-gelatinized starches obtained from wheat and waxy maize. 
Table III

Initial and final body weight, SGR, RGR, survival and shear force of crayfish A. astacus fed the experimental treatments.

Tableau III

Poids initial et final, SGR, RGR, survie et force de traction des écrevisses $A$. astacus alimentées selon les quatre traitements.

\begin{tabular}{lccccc}
\hline \multicolumn{1}{c}{ Variables } & D1-Wheat & $\begin{array}{c}\text { D2-Waxy } \\
\text { Maize }\end{array}$ & D3-Maize & D4-Potato & $\begin{array}{c}\text { Err. Var. } \\
\text { (6 d.f.) }\end{array}$ \\
\hline Initial weight (g) & 0.67 & 0.74 & 0.79 & 0.67 & 0.020 \\
Final weight (g) & $1.20^{\mathrm{a}}$ & $1.24^{\mathrm{a}}$ & $1.16^{\mathrm{b}}$ & $0.97^{\mathrm{c}}$ & 0.033 \\
SGR $^{1}$ & $3.19^{\mathrm{a}}$ & $3.16^{\mathrm{a}}$ & $2.30^{\mathrm{b}}$ & $1.58^{\mathrm{c}}$ & 1.10 \\
$\mathrm{RGR}^{2}$ (\%) & $79^{\mathrm{a}}$ & $68^{\mathrm{a}}$ & $46^{\mathrm{b}}$ & $45^{\mathrm{b}}$ & 329 \\
Survival " & $96^{\mathrm{a}}$ & $93^{\mathrm{a}}$ & $84^{\mathrm{b}}$ & $97^{\mathrm{a}}$ & 78 \\
Shear force (g) & $7701.2^{\mathrm{a}}$ & $7794.2^{\mathrm{a}}$ & $5583.2^{\mathrm{b}}$ & $6132.2^{\mathrm{b}}$ & 31.57 \\
\hline
\end{tabular}

Means with different superscripts within the same row are significantly different $(a, b P<0.05)$.

1 SGR: Specific Growth Rate, ((In[final weight] - In[initial weight]) × 100)/days.

2 RGR: Relative growth rate:((final b.w. - initial b.w.)/(initial b.w.).

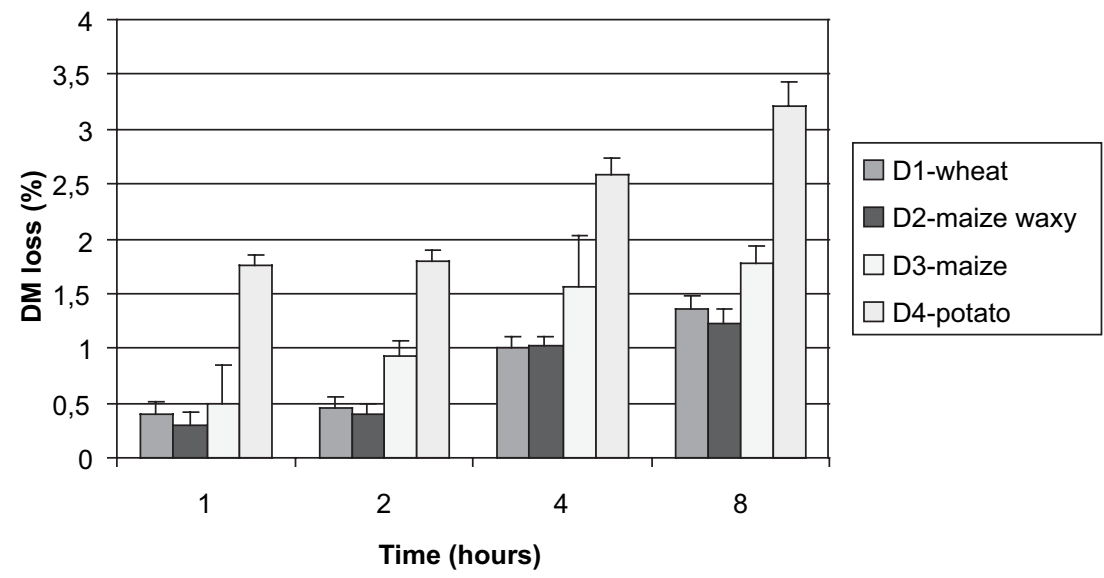

Figure 1

Dry matter losses of the experimental diets after immersion into the water for 1 , 2, 4 and 8 hours.

\section{Figure 1}

Pertes en matières sèches des aliments des différents régimes après immersion dans l'eau pendant 1, 2, 4 ou 8 heures.

\section{DISCUSSION}

Pre-gelatinized starches are incorporated into crayfish feeds to supply carbohydrates and improve stability in water, increase pellet firmness, and reduce the amount of fines produced during processing and handling. Conditions for a proper reaction between the binder and feed ingredients during the polluting process have to be optimized. Several starches can be used to prepare crayfish feeds (CUZON et al., 1994). The American 


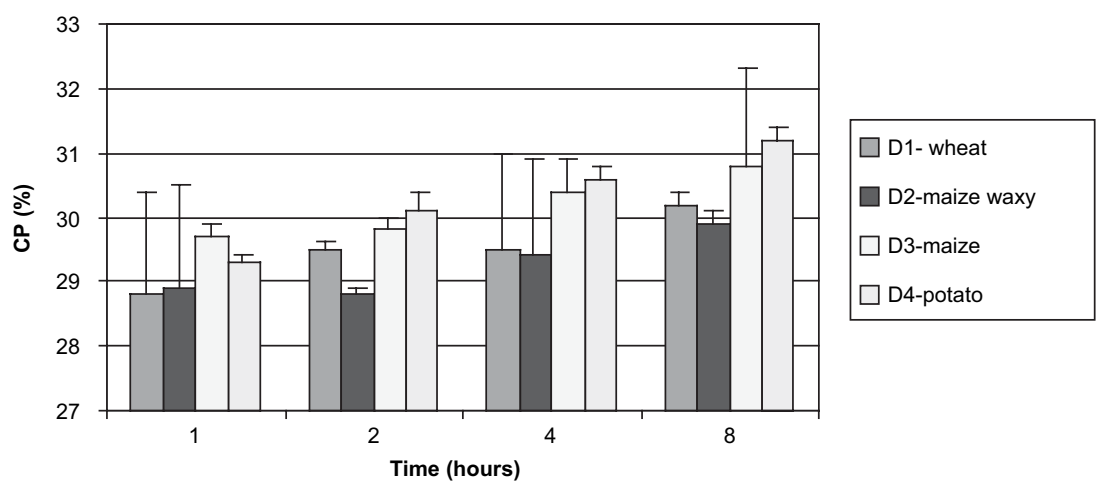

Figure 2

Crude protein contents (\% DM) of the experimental diets after immersion into the water for 1, 2, 4 and 8 hours.

\section{Figure 2}

Contenu en protéines (en $\%$ du poids sec) des régimes alimentaires après immersion dans l'eau pendant 1, 2, 4 ou 8 heures.

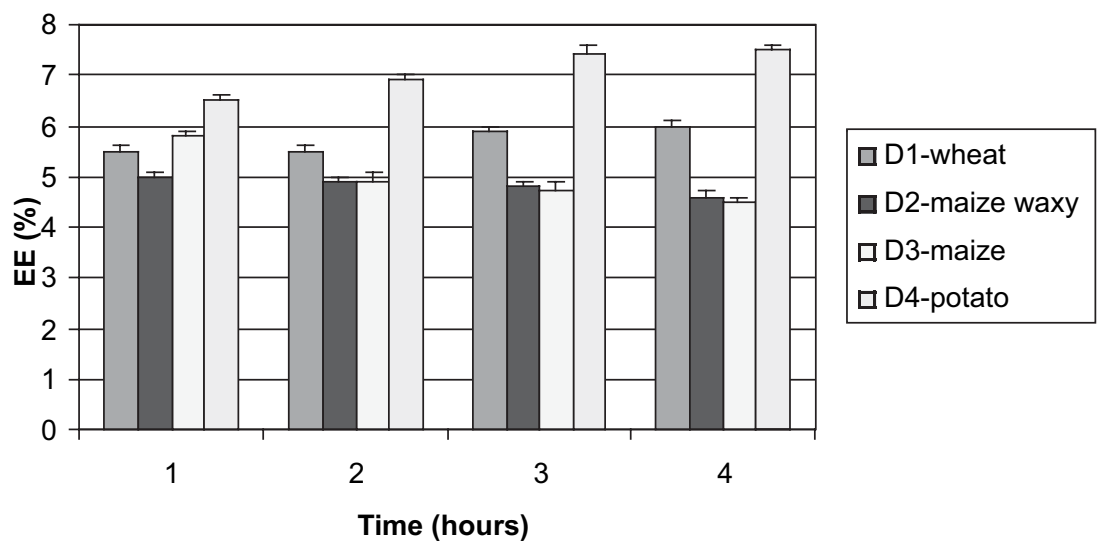

\section{Figure 3}

Ether extract contents of the experimental diets after immersion into the water for 1, 2, 4 and 8 hours.

\section{Figure 3}

Contenu en extraits d'éther des régimes alimentaires expérimentaux après immersion dans l'eau pendant 1, 2, 4 ou 8 heures.

National Formulary has classified all the starches obtained from different botanical sources (corn, wheat and potato, etc.) (DOMINY and LIM, 1992). The amylose and amylopectin contents of the starches as well as their particle size and shape are known to depend on the botanical source (DOMINY and LIM, 1992). ACKEFORS and TÖRÖK (2002) reported that a higher proportion of fibre resulted in larger volumes of nutrient material lost through disintegration of pellets into the water and lower growth rates.

In the present study, substantial differences were found among the four diets concerning the growth rate. All diets were apparently adequate in crude protein and energy contents for crayfish growth. ACKEFORS et al. (1992) tested in juveniles Astacus astacus twelve pelleted diets containing various combinations of protein, lipid and 
carbohydrates. Optimum growth rate was achieved with a protein/energy ratio of $114 \mathrm{mg} /$ kcal. Variations in growth and survival rates of crayfish were associated with differences in dry matter losses and chemical compositions of the diets after immersion into the water. The diets supporting reduced growth rate (diet 3 (maize) and 4 (potato)) had also a lower hardness and higher dry matter loss. Crayfish fed with stable diets showed larger weight increments than the groups fed with similar unstable diets (JUSSILA and EVANS, 1998). FAIR and FORTNER (1981) compared the growth responses of the freshwater Macrobrachium rosenbergii fed a water stable diet and a pulverized form of the pelleted diet. Results of their work suggest a more efficient nutrition using water stable diets. Several factors may influence the water stability of a diet. RUSCOE et al., (2002) found a significant difference between a salmonid and a formulated crayfish diet in terms of solubility although the crayfish biomass gain was similar during the growth trial. According to BALAZS et al. (1973), the insufficient amount of water, during the production phase, determines a lack of cohesion among particles. Most of the amount of dry matter loss was evident after 2-4 $\mathrm{h}$ for all the diets. After that period of time, there was a lower and gradual increase of the dry matter loss up to $8 \mathrm{~h}$. A similar trend was also observed by SARAC et al. (1993) using a commercial feed for prawns and by CUZON et al. (1982) in Paeneus Japonicus. In contrast, JONES et al. (1996a, b) reported a high dry matter loss $1 \mathrm{~h}$ after the addition of the pellets to the water and only small losses occurred after $2 \mathrm{~h}$. In their experiments, the inclusion of high levels of soybean meal, wheat flour, snail and zooplankton as main ingredients in the formulation of the diets played an important role to the rapid increase of the rate of dry matter loss. A dry matter loss below of $10 \%$ after $1 \mathrm{~h}$ is generally considered a good value for crustacean diets (CUZON et al., 1994). From a practical point of view and under intensive farming conditions, results of the present and previous studies may suggest feeding freshwater crayfish using automatic feeders every 2-4 h. After the immersion of diets into the water, carbohydrates were promptly solubilized leading to an increase of protein and lipid concentrations. In line with these findings, HASTING and MILLER (1961) reported a higher loss of soluble starch and sugars compared to soluble proteins.

\section{CONCLUSION}

Results of the present experiment suggest that the pre-gelatinized wheat and waxy starches are the best choice in noble crayfish diets in order to increase the feed stability in water and growth performance.

\section{REFERENCES}

ACKEFORS H., CASTELL J.D., BOSTON L., RATY P., SVENSSON M., 1992. Standard experimental diets for crustacean nutrition research. II. Growth and survival of juvenile crayfish Astacus astacus (Linné) fed diets containing various amounts of protein, carbohydrate and lipid. Aquaculture, 104, 341-356.

ACKEFORS A., TÖRÖK K., 2002. Experimental studies on nutrient release by noble crayfish, Astacus astacus L., fed two different diets. Freshwater Crayfish, 13, 41-57.

A.O.A.C., 1990. Official Methods of Analysis, $15^{\text {th }}$ edition. Association of Official Analytical Chemists (AOAC). Washington, DC.

APHA, 1980. Standard Methods for the Examination of Water and Wastewater, $15^{\text {th }}$ edition. American Public Health Association. Washington, DC.

BALAZS G., ROSS E., BROOKS C.C., 1973. Preliminary studies on the preparation and feeding of crustacean diets. Aquaculture, 2, 369-377. 
BOONYARATPALIN M., NEW M.B., 1995. On-farm feed preparation and feeding strategies for marine shrimp and freshwater prawns. In: NEW M.B., TACON A.G.J., CSAVAS I. (Eds.). Farm-made aquafeeds. FAO Fisheries Technical Paper $N^{\circ} 343,120-134$, FAO, Rome.

CUZON G., GUILLAUME J., CAHU, C., 1994. Composition, preparation and utilization of feeds for crustacea. Aquaculture, 124, 253-267.

CUZON G., HEW M., COGNIE D., SOLETCHNIK P., 1982. Time lag effect of feeding on growth of juvenile shrimp, Penaeus japonicus Bate. Aquaculture, 29, 33-44.

DOMINY W., LIM C., 1992. Performance of binders in pelleted shrimp diets. In: AKIYAMA D., TAN R. (Eds.). Proc. on Aquaculture Feed Processing and Nutrition, 149-157, ASA, Singapore.

FAIR P.H., FORTNER A.R., 1981. The role of formula feeds and natural productivity in the culture of the prawn, Macrobrachium rosenbergii. Aquaculture, 24, 233-240.

HASTINGS W.H., 1964. Fish feed processing research. Feedstuffs, 36, 13.

HASTINGS W.H., MEYERS S.P., BUTLER D.P., 1971. A commercial process for waterstable fish. Feedstuffs, 43, 38.

HASTINGS W.H., MILLER G.D., 1961. Biochemical changes in grains. Cereal Science Today, 6, 6-8.

JONES P.L., DE SILVA S.S., MITCHELL, B.D., 1996a. Effects of replacement of animal protein by soybean meal on growth and carcass composition in juvenile Australian freshwater crayfish. Aquaculture International, 4, 339-359.

JONES P.L., DE SILVA S.S., MITCHELL B.D., 1996b. The effect of dietary protein source on growth and carcass composition in juvenile Australian freshwater crayfish, Aquaculture International, 4, 361-376.

JUSSILA J., EVANS L.H., 1998. Growth and condition of marron Cherax tenuimanus fed pelleted diets of different stability, Aquaculture Nutrition, 4, 143-149.

RUSCOE I.M., JONES P.L., JONES C.M., 2002. Effects of feeding moist and dry diets redclaw crayfish, Cheax quadricarinatus, in tanks. Freshwater Crayfish, 13, 164176.

SARAC Z., THAGGARD H., SAUNDERS J., GRAVEL M., NEILL A., COWAN R.T., 1993. Observations on the chemical composition of some commercial prawn feeds and associated growth responses in Penaeus monodon. Aquaculture, 115, 97-110.

SAS, 1989. SAS User's Guide. $4^{\text {th }}$ ed. SAS Institute, Cary, NC, USA. 
